\title{
Redistribution of Chernobyl-derived radiocaesium across the landscape: Field observations and spatial modelling
}

\author{
M. Van der Perk, O. Slavik ${ }^{1}$ and A. Svetlitchnyi ${ }^{2}$ \\ Utrecht Centre for Environment and Landscape Dynamics-UCEL, Faculty of Geographical \\ Sciences, Utrecht University, P.O. Box 80115, 3508 TC Utrecht, The Netherlands \\ ${ }^{1}$ VUJE Trnava a.s., Okruzna 5, 91864 Trnava, Slovakia \\ ${ }^{2}$ Department of Physical Geography, Odessa State I.I. Mechicov University, \\ Shampansky Per. 2, 270058 Odessa, Ukraine
}

\begin{abstract}
In the framework of the EC-funded SPARTACUS project, redistribution of Chernobyl-derived radiocaesium at the catchment scale due to runoff and soil erosion and deposition was evaluated by means of rainfall experiments, soil sampling, and spatial modelling. Two GIS-embedded models have been developed, which simulate lateral radiocaesium transport at the event scale and long-term radiocaesium redistribution, respectively. The results from the rainfall experiments and model calculations demonstrate that from the runoff plots and on steep hill slopes where erosion rates are largest, the ${ }^{137} \mathrm{Cs}$ transport occurs mainly in particulate form. Due to internal deposition, the contribution of particulate ${ }^{137} \mathrm{Cs}$ transport to total ${ }^{137} \mathrm{Cs}$ transport decreases with increasing catchment size. During the fifteen years since the accident, soil contamination by radiocaesium has decreased by a factor of 3 to 4 at the steep hill slopes as a result of both radioactive decay and soil erosion. In the valley bottoms, inputs of radiocacsium aftached to deposited soil particles have maintained the soil contamination at the 1986 level. The spatial patterns of radiocaesium gains and losses during individual rainfall events resemble the long-term patterns.
\end{abstract}

\section{INTRODUCTION}

In the years following the Chernobyl accident in April 1986, surface contamination by radiocaesium $\left({ }^{137} \mathrm{Cs}\right.$ ) has been subject to changes not only due to physical decay (physical half-life of 30.2 y), but also as a result of lateral transport of contaminated water and soil particles. This ${ }^{137} \mathrm{Cs}$ transport has resulted in a still ongoing transfer of radionuclides from terrestrial ecosystems to surface water, bed sediments, and floodplains. For an appropriate assessment of pathways by which radioactivity is transferred within ecosystems, it is essential to consider redistribution processes that affect the initial ${ }^{137} \mathrm{Cs}$ deposition patterns.

The mobility and fate of radiocaesium in landscapes is largely determined by its geochemistry. Radiocaesium is very soluble in water, but also readily specifically adsorbed by illitic clay minerals [1]. As a consequence, ${ }^{137} \mathrm{Cs}$ becomes irreversibly fixed in mineral soils to clay minerals over the years, whereas in organic soils it remains mobile, which has been demonstrated by many authors (e.g. [2]). Hence, the transport of ${ }^{137} \mathrm{Cs}$ from and redistribution within agricultural and natural catchments on the long term is mainly related to transport of fine sediments, although the initial post-accidental transport of ${ }^{137} \mathrm{Cs}$ might largely have occurred in dissolved form $[2,3]$.

Most modelling studies on radionuclide redistribution have focussed on the transfer from tertestrial to aquatic ecosystems. (e.g. [4], [5], [6]), which have yielded aggregated predictions at the scale of entire catchments. Moreover, most of these model studies have only considered dissolved radionuclide transport. Spatially distributed erosion and sedimentation models have not been widely used for evaluation of transport within and from river catchments, although ${ }^{137} \mathrm{Cs}$ has been used as tracer in many soil erosion modelling studies (e.g. [7]).

This paper aims to assess the role of soil erosion and deposition for ${ }^{137} \mathrm{Cs}$ redistribution across the landscape. Besides runoff experiments, an event-based and a long-term ${ }^{137} \mathrm{Cs}$ redistribution model have been developed. These models have been embedded in the spatio-temporal modelling language of the PCRaster GIS [8].

The field studies to collect experimental data to feed and validate the models were focussed on the Butenya catchment, Boguslav and Mironov districts, Ukraine, and the Mochovce catchment, Slovakia (figure 1).The Butenya river catchment $\left(49^{\circ} 36^{\prime} \mathrm{N}, 30^{\circ} 53^{\prime} \mathrm{E}\right)$ has a typical erosion relief with steep slopes (up to $20^{\circ}$ ) and height differences of about $50 \mathrm{~m}$. Podsolised grey forest soils and chernozem soils on 
loess are predominant in this area. According to the Atlas of Caesjum deposition on Europe [9] the level of post-Chernobyl deposition by ${ }^{137} \mathrm{Cs}$ amounts to $40-185 \mathrm{kBq} \mathrm{m}$. The Mochovce catchment $\left(48^{\circ} 16^{\prime} \mathrm{N}\right.$ $\left.18^{\circ} 26^{\prime} \mathrm{E}\right)\left(3.7 \mathrm{~km}^{2}\right)$ is situated in the hilly part of the Danube Lowlands in Western Slovakia. An artificial channel drains the upper part of the catchment. In the central part of the catchment a natural spring zone feeds a small strean flowing through a marshland in the broad valley bottom before it reaches the catchment outlet. The main land use is termophilous oak forest $(2.1 \mathrm{~km} 2)$ and arable land $\left(1.4 \mathrm{~km}^{2}\right)$. Because nunoff and erosion do not occur in the forested part of the catchment, the study has focused on the arable part. Haplic Luvisols with a clayey loamy texture are the main soil type on the hillslopes under agricultural use. The post-Chernobyl ${ }^{137} \mathrm{Cs}$ deposition amounts to $13 \mathrm{kBq} \mathrm{m^{-2 }}$.

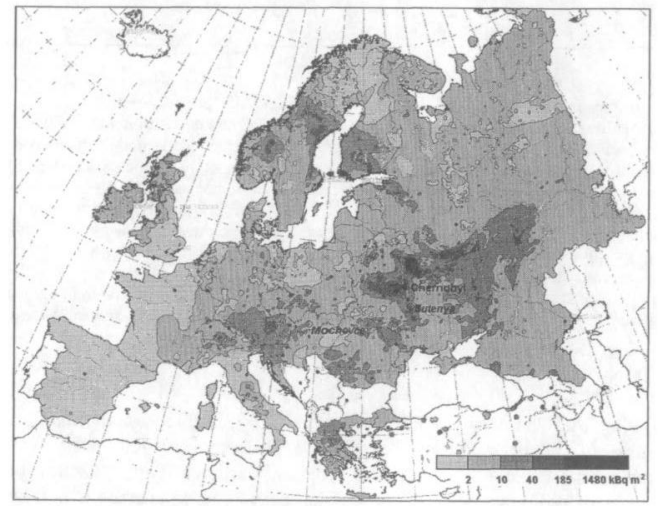

Figure 1: Location of the pilot catchnents and radiocaesium contamination by the Chemobyl sccident (source: [9]).

\section{FIELD OBSERVATIONS}

\subsection{Radiocaesium wash-off from runoff plots in the Butenya catchment}

In August 1999, artificial rainfall experiments were carried out at six selected locations with typical soil types in the Butenya catchment, Ukraine, to evaluate ${ }^{137} \mathrm{Cs}$ wash-off at the plot scale. For this purpose, a sprinkler designed at the Odessa Hydro-meteorological Institute and subsequently modified at Odessa State I.I. Mechnicov University [10] was used. At each location two representative plots of $1 \mathrm{~m}^{2}$ were selected, from which the litter was removed. Subsequently the plots were wetted and sprinkled with an ultimate rainfall intensity of $150 \mathrm{~mm}$ hour ${ }^{-1}$ until the runoff reached a steady state condition. Five to six water samples with a volume of about 1 litre were collected in the last 10 minutes of experiment. After the experiment, soil samples from the plots were collected for the determination of grain size distribution and radiocaesium activity concentration.

Table 1 shows that more than $90 \%$ (and in some cases more than $99 \%$ ) of the transported ${ }^{137} \mathrm{Cs}$ is adsorbed to sediment particles. The $K d$ value varies between 3 and $17 \mathrm{~m}^{3} \mathrm{~kg}^{-1}$. Figure 2 shows a typical distribution of ${ }^{137} \mathrm{Cs}$ over the various grain size fractions for both soil and sediment from the Youkhny-1 experimental plot. The analyses from the other plots show similar results. The grain size distribution of the transported sediments is practically the same as the grain size distribution for the top soil layer of the experimental plots. The fraction between 10 and $50 \mu \mathrm{m}$ comprises more than $70 \%$ of the sample's weight. This fraction carries most of the adsorbed ${ }^{137} \mathrm{Cs}$ and therefore, it accounts for $47-74 \%$ of the ${ }^{37} \mathrm{Cs}$ transport. The entire sediment fraction smaller than $50 \mu \mathrm{m}$ accounts for $90-97 \%$ of the ${ }^{137} \mathrm{Cs}$ transport. 
Table 1: Characteristics of ${ }^{137} \mathrm{Cs}$ wash-off during rainfall experiments in the Butenya river basin

\begin{tabular}{|c|c|c|c|c|c|c|c|}
\hline \multirow{3}{*}{$\begin{array}{l}\text { Experimental } \\
\text { site }\end{array}$} & \multirow[t]{3}{*}{ Soil type } & \multirow{3}{*}{$\begin{array}{l}\text { Slope } \\
\text { gradient } \\
\%\end{array}$} & \multirow{3}{*}{$\begin{array}{l}\text { Mean } \\
\text { sediment } \\
\text { concentration } \\
\mathrm{kg} \mathrm{m}^{-3}\end{array}$} & \multicolumn{3}{|c|}{ Cs-137 activity concentration } & \multirow[t]{2}{*}{$\bar{K} d$} \\
\hline & & & & dissolved & particulate & particulate & \\
\hline & & & & $\mathrm{Bq} \mathrm{m}^{3}$ & $\mathrm{~Bq} \mathrm{~m}^{3}$ & $\mathrm{~Bq} \mathrm{~kg}^{\prime}$ & $\mathbf{m}^{3} \mathbf{k g}^{-1}$ \\
\hline \multirow[t]{2}{*}{ Ploskyi } & Podsolised Dark Grey Forest & 4.5 & 8.586 & 63 & 2456 & 286 & 4.54 \\
\hline & Soil & 4.5 & 11.532 & 47 & 1730 & 150 & 3.19 \\
\hline \multirow{2}{*}{ Lesnaya-2 } & Slightly Eroded, Podsolised & 6.8 & 7.957 & 51 & 4536 & 570 & 11.18 \\
\hline & Grey Forest Soil & 6.1 & 15.248 & 29 & 8691 & 570 & 16.66 \\
\hline \multirow[t]{2}{*}{ Vladislavka-1 } & Typical Chemozem & 5.5 & 9.040 & 47 & 3761 & 416 & 8.85 \\
\hline & & 5.4 & 15.445 & 30 & 4803 & 311 & 10.37 \\
\hline \multirow[t]{2}{*}{ Ecological } & Slightly Eroded, Podsolised & 5.9 & $1 . \overline{928}$ & 26 & 318 & 165 & 6.35 \\
\hline & Chernozem & 5.4 & 5.629 & 8 & 467 & 83 & 10.38 \\
\hline \multirow{2}{*}{ Youkhny-1 } & Leached Chernozen & 4.6 & 6.226 & 24 & 1476 & 237 & 9.88 \\
\hline & & 4.8 & 13.583 & 26 & 3817 & 281 & 10.81 \\
\hline \multirow[t]{2}{*}{ Youkhny-2 } & Moderately Eroded, Leached & 6.1 & 30.521 & 18 & 2765 & 91 & 5.06 \\
\hline & Chernozem & 5.1 & 15.957 & 23 & 2984 & 187 & 8.13 \\
\hline
\end{tabular}

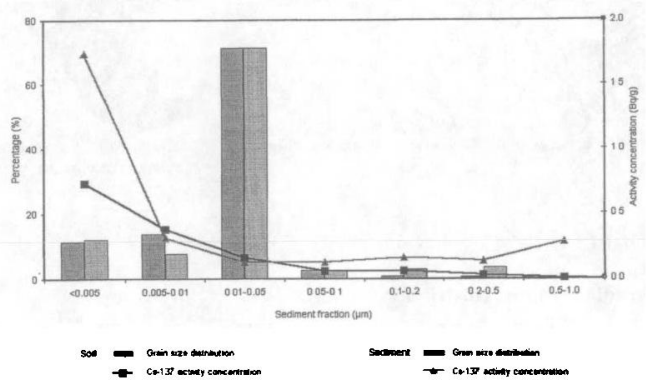

Figure 2: Grain size distribution and distribution of ${ }^{137} \mathrm{Cs}$ over the graion size fractions for soil and sediment from the Youkhny-1 experimental plot.

\subsection{Spatial distribution of radiocaesium in the Mochovce catchment}

In July 1999, 180 samples from the topsoil up to 35 to $55 \mathrm{~cm}$ depth were collected in the arable part of Mochovce catchment. Seventy-seven sampling points were located in a regular grid using a sampling interval of $100 * 200 \mathrm{~m}$ (figure 3) in order to obtain an unbiased estimation of the average ${ }^{137} \mathrm{Cs}$ activity in the study area. To study local variation of ${ }^{137} \mathrm{Cs}$ in soil a representative sub-catchment in the northerm part of the catchment (about $150 \mathrm{~m}$ wide and $300 \mathrm{~m}$ long) was selected. In this sub-catchment, 80 sampling points were distributed over 12 transects perpendicular to the elevation contours. Each sample consisted of three subsamples collected in a triangle at a mutual distance of $50 \mathrm{~cm}$. The samples were dried, weighed, and analysed for ${ }^{137} \mathrm{Cs}$. The ${ }^{137} \mathrm{Cs}$ values were expressed in $\mathrm{Bq} \mathrm{m}$.

Subsequently, the ${ }^{137} \mathrm{Cs}$ values were interpolated by means by means of universal kriging, a geostatistical interpolation technique that uses external variables to improve the spatial prediction [11]. In this case, a sediment budget index, which was calculated in a similar way as the long term erosion and deposition rates by the long-term ${ }^{137} \mathrm{Cs}$ redistribution model presented in section 3.2 , and the profile curvature derived from the digital elevation model (DEM) of the catchment were used as external variables in the kriging procedure. 
Figure 4 shows the interpolated spatial pattern of ${ }^{137} \mathrm{Cs}$ inventories in soil. The predicted pattern obviously shows the enhancement of ${ }^{137} \mathrm{Cs}$ inventories in the valley bottoms due to deposition of sediment eroded on upstream parts of the hill slopes. Particularly at the steep slopes in the eastem part of the catchment much ${ }^{137} \mathrm{Cs}$ has been removed since the initial deposition and has been transported to downstream areas.

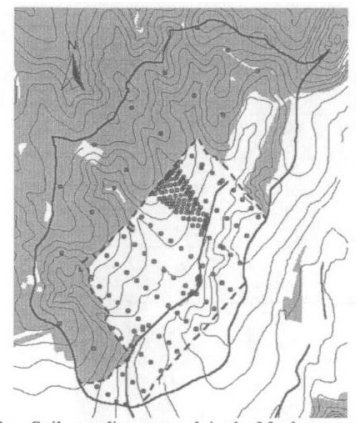

Figure 3: Soil sampling network in the Mochovce catchment

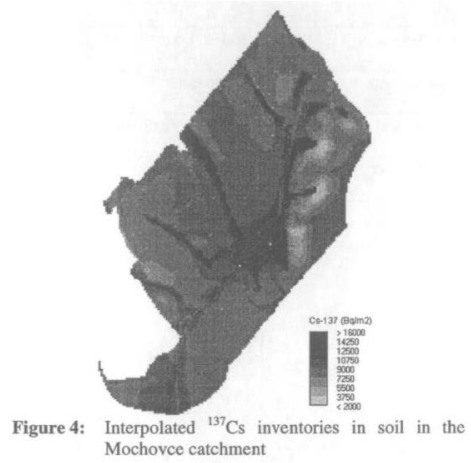

Mochovce catchment

\section{SPATIAL MODELLING}

\subsection{Event-based radiocaesium redistribution model}

The event-based ${ }^{137} \mathrm{Cs}$ redistribution model was based on the existing LISEM soil erosion model [12], which accounts for interception, infiltration, surface runoff, splash and flow detachment, suspended sediment transport and deposition during individual rainfall events. Radiocaesium exchange between the adsorbed phase in the topsoil layer and the dissolved phase in the runoff water and between the dissolved phase and adsorbed phase in the suspended sediment is calculated by means of $K d$ values. It is assumed that equilibrium between the adsorbed and dissolved phases is reached instantaneously. The $K d$ values are estimated as function of sediment type and time since initial deposition and are assumed to be constant throughout the rainfall event. The ${ }^{13} \mathrm{Cs}$ activity concentration in the topsoil is estimated using soil bulk density and either an exponential depth distribution before the first ploughing or a uniform depth distribution over the plough layer after the first ploughing.

The simulated discharge was calibrated against observed discharge for the 10-11 July 1999 rainfall event ( $6.4 \mathrm{~mm}$ rainfall) in the Mochovce catchment. The $K d$ value for exchange between the topsoil and the runoff water was estimated at $13.2 \mathrm{~m}^{3} \mathrm{~kg}^{-1}$ and the $K d$ value for exchange between suspended sediment and the runoff water was estimated at $39.7 \mathrm{~m}^{3} \mathrm{~kg}^{-1}$. Figure 5 shows the discharge, sediment and ${ }^{137} \mathrm{Cs}$ flux during this rainfall event. Over the entire simulated event, the ${ }^{137} \mathrm{Cs}$ transport from the Mochovce catchment occurred for about $50 \%$ in dissolved form, but during maximum sediment discharge this percentage is amounts to about $30 \%$. At the steep slopes in the eastern part of the catchment where erosion rates are the largest in the catchment, more than $99 \%$ of ${ }^{137} \mathrm{Cs}$ transport occurs in particulate form. Figure 6 shows the spatial distribution of simulated total ${ }^{137} \mathrm{Cs}$ transport during peak discharge. The ${ }^{137} \mathrm{Cs}$ transported through the main channel in the catchment is mainly fed from a limited number of side-valleys. 


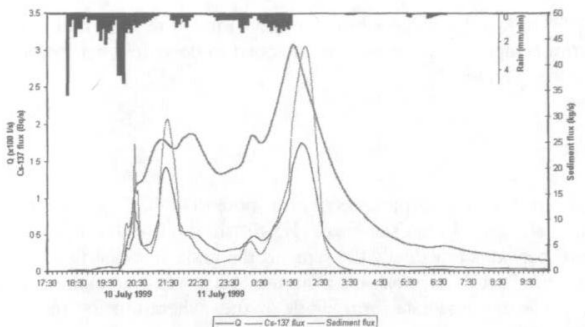

Figure 5: Discharge, sediment and ${ }^{137} \mathrm{Cs}$ transport from the Mochovce catchment during the 10-11 July 1999 rainfall event



\subsection{Long-term radiocaesium redistribution model}

The model of long-term ${ }^{137} \mathrm{Cs}$ redistribution predicts soil contamination by ${ }^{137} \mathrm{Cs}$ as a result of soil erosion and deposition and radioactive decay with a monthly time step. For this purpose, a soil erosion is calculated based on a rill erosion model described by [13]:

$$
E_{r}=a L^{n} S^{m}
$$

Where $E_{r}=$ potential erosion rate per unit area $(-), L=$ slope length $(\mathrm{m}), S=$ slope gradient $(-), a, n, m$ $=$ parameters. Both the slope length and the slope gradient are derived from the DEM. The sediment transport capacity on a given location in the catchment is considered to be directly proportional to the potential for erosion [13]. The amount of eroded material per grid cell is transported downstream over the drainage network, as long as it does not exceed the transport capacity. The surplus is deposited. In the first months after initial ${ }^{137} \mathrm{Cs}$ deposition, all ${ }^{137} \mathrm{Cs}$ is assumed to be in a thin layer of $5 \mathrm{~mm}$ in the top soil. After a user-defined period, the ${ }^{137} \mathrm{Cs}$ is redistributed uniformly over the plough depth. The ${ }^{137} \mathrm{Cs}$ inventories in soil $\left(\mathrm{Bq} \mathrm{m}^{-2}\right)$ are converted into activity concentrations using soil bulk density and the depth over which the ${ }^{137} \mathrm{Cs}$ is distributed. At erosion sites the ${ }^{137} \mathrm{Cs}$ loss from the soil is calculated by multiplying the ${ }^{137} \mathrm{C}$ activity concentration of the topsoil by the erosion rate. At deposition sites the ${ }^{137} \mathrm{Cs}$ input the upper soil is calculated by multiplying the weighted activity concentrations at the upstream erosion sites by the deposition rate. Once per year, during the month of ploughing the available ${ }^{37} \mathrm{Cs}$ is redistributed over the plough layer.

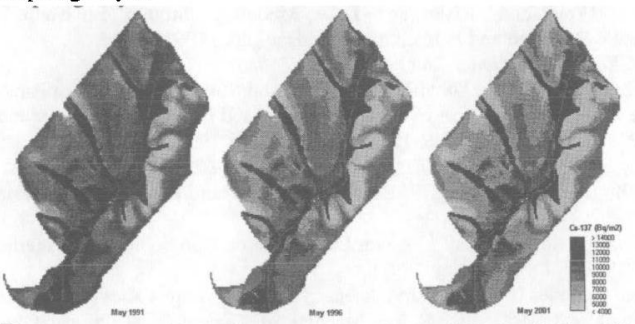

Figure 7: Simulated ${ }^{137} \mathrm{Cs}$ inventories in soil in the Mochovce catchment in May 1991, May 1996, and May 2001

The model has been calibrated for the Mochovce catchment using the observed ${ }^{137} \mathrm{Cs}$ inventories in soil (see section 2.2). Figure 7 shows the simulation results for 5, 10, and 15 years after initial deposition of Chemobyl-derived ${ }^{137} \mathrm{Cs}$. During the fifteen years since the accident, soil contamination by 
radiocaesium has decreased by a factor of 3 to 4 at the steeper hill slopes as a result of both radioactive decay and soil erosion. In the valley bottoms, inputs of radiocaesium attached to deposited soil particles have maintained the soil contamination at the 1986 level.

\section{DISCUSSION AND CONCLUSIONS}

The observed ${ }^{137} \mathrm{Cs}$ wash-off from the experimental runoff plots occurs for more than $90 \%$ in particulate form, almost entirely by soil particles smaller than $50 \mu \mathrm{m}$. The grain size distribution of the transported sediments aggregated over the entire runoff period is practically the same as the grain size distribution for the top soil layer of the experimental site. Simulated ${ }^{137} \mathrm{Cs}$ wash-off from the Mochovce catchment during a $6.4 \mathrm{~mm}$ rainfall event occurs for about $50 \%$ in particulate form, while at sites where erosion rates are largest, ${ }^{137} \mathrm{Cs}$ transport occurs for more than $99 \%$ in particulate form.

It can be concluded that particulate ${ }^{137} \mathrm{Cs}$ wash-off is most important at sites with large erosion and sediment transport rates. Due to internal sediment deposition, the proportion particulate ${ }^{{ }^{37} \mathrm{Cs} \text { transport }}$ decreases with catchment size. The major part of the redistributed ${ }^{137} \mathrm{Cs}$ remains together with the sediments within the study catchments at the lower parts of the slopes, valley floors and floodplains. The radiocaesium export from the catchment is very sensitive to the amount of soil particles that is transferred from the valley bottoms to the river channel, which is often affected by local phenomena such as local barriers or buffer strips that prevent direct flow to the river channel. The cumulative effect of rainfall events results in a changing pattern of ${ }^{137} \mathrm{Cs}$ inventories in soil. At sites where erosion occurs, the amount of ${ }^{137} \mathrm{Cs}$ is reduced by a factor of 3 to 4 , whilst in the valley floors where deposition occurs the ${ }^{137} \mathrm{Cs}$ levels have, despite radioactive decay, remained at the levels of initial deposition.

\section{Acknowledgements}

The SPARTACUS project was funded by the European Commission (EC Contract No. IC15CT980215). The authors are grateful to all co-workers of the SPARTACUS project who participated in fieldwork and useful discussions.

\section{References}

[1] A. Cremers, A. Elsen, and P. De Preter, Nature 335 (1988) 247-249.

[2] J. Hilton, F.R. Livens, P. Spezzano, and D.R.P. Leonard, Sci. Tot. Environ. 129 (1993) 253-266.

[3] O. Slávik, M. Zheleznyak, N. Dzuba, A. Marinets, G. Lyashenko, L. Papush, T. Shepeleva, and B. Mihaly Rad. Prot. Dosim. 73 (1997) 171-176.

[4] B.S. Shukla, Watershed, River and Lake Modeling through Environmental Radioactivity (Environmental Research and Publications Inc., Hamilton, 1993).

[5] L. Monte, J. Environ. Radioact. 26 (1995) 71-82.

[6] U. Sansone, and O.V. Voitsekhovitch, Modelling and Study of the Mechanisms of the Transfer of Radioactive Material from Terrestrial Ecosystems to and in Water Bodies around Chemobyl; Final Report ECP3 (EC Report No. EUR 16529, Luxembourg, 1996).

[7] D.E. Walling and Q. He, J. Environ. Qual. 28 (1999) 611-622.

[8] C.G. Wesseling, D. Karssenberg, W.P.A. van Deursen, and P.A. Burrough, Trans. GIS 1 (1996) 40-48.

[9] European Commission, Atlas of Caesium Deposition on Europe after the Chernobyl Accident (EC Report EUR 16733, Luxembourg, 1998).

[10] H.I. Shvebs, Principles of Soil Erosion Science (Naukova Dumka Kiev-Odessa, 1981)(in Russian).

[11] P.A. Burrough and McDonnel R.A., Princples of Geographical Information Systems. Oxford University Press, Oxford, 1998).

[12] A.P.J. de Roo, C.G. Wesseling, and C.J. Ritsema, Hydrol. Proc. 10 (1996) 1107-1117

[13] Govers G., Quine T.A. and Walling D.E., in Farm Land Erosion in Temperate Plains and Hills, edited by S. Wicherek (Elsevier, Amsterdam, 1993), pp. 285-300. 